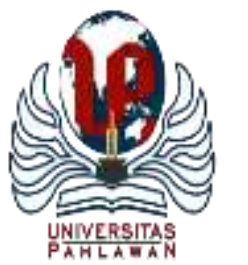

Edukatif : Jurnal Ilmu Pendidikan Volume 3 Nomor 6 Tahun 2021 Halm 4970 - 4979

EDUKATIF: JURNAL ILMU PENDIDIKAN

Research \& Learning in Education

https:/ledukatif.org/index.php/edukatif/index

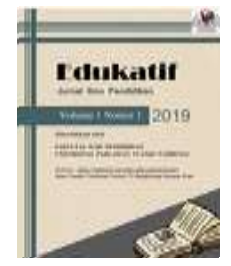

\title{
Strategi Guru dalam Menumbuhkan Jiwa Nasionalisme Peserta Didik melalui Pembelajaran Pkn
}

\section{Syofiyah Hasna $^{1 凶}$, Amanda Ramadhan Firdaus², Dinie Anggraeni Dewi Yayang Furi Furnamasari ${ }^{4}$ \\ Universitas Pendidikan Indonesia, Indonesia ${ }^{1,2,3,4}$}

E-mail : syofiyahhasna@ upi.edu ${ }^{1}, \underline{\text { amanda12@upi.edu }}^{2},{\underline{\text { dinieanggaraenidewi@ } \text { upi.edu }^{3}}}^{3} \underline{\text { furi2810@ }}_{\text {upi.edu }}{ }^{4}$

\begin{abstract}
Abstrak
Penelitian ini dilatarbelakangi oleh kesadaran nasionalis anak-anak di negara Indonesia yang menurun menjadi fokus tersendiri, seperti sikap dan perilaku sosial anak, remaja, dan generasi muda saat ini dan kemerosotan generasi muda telah menyebabkan penurunan kesadaran nasionalis. Penelitian ini bertujuan untuk mendeskripsikan peran guru dalam membentuk karakter nasionalisme siswa sekolah dasar dan pentingnya pembelajaran Pendidikan Kewarganegaraan dalam membentuk jiwa nasionalisme pada siswa. Penelitian ini menggunakan pendekatan kualitatif dan deskriptif, dengan teori atau landasan yang bersumber dari penelitian kepustakaan, yang mencakup berbagai sumber seperti buku, jurnal, dan artikel. Metode ini menitikberatkan pada pemahaman fenomena sosial yang terjadi di masyarakat dan digunakan untuk menentukan kebenaran dalam suatu realitas yang terjadi. Hasil penelitian ini menunjukkan bahwa mata pelajaran PKn menaruh anak didik citra buat mempunyai perilaku yg berkarakter misalnya semangat nasionalisme dan patriotism. Dan tugas guru PKn lebih dari sekadar menyampaikan gagasan tentang bagaimana menjadi warga negara yang baik kepada siswa itu juga memerlukan pemberian pengetahuan, motivasi, menanamkan pola pikir, dan mempromosikan sikap dan perilaku etis yang sangat baik.
\end{abstract}

Kata Kunci: jiwa nasionalisme, peran guru, pendidikan kewarganegaraan.

\section{Abstract}

This research is motivated by the declining nationalist awareness of children in Indonesia which has become a separate focus, such as the attitudes and social behavior of children, adolescents and young people today and the decline of the younger generation has led to a decline in nationalist awareness. This study aims to describe the role of teachers in shaping the nationalist character of elementary school students and the importance of learning citizenship education in shaping the spirit of nationalism in students. This study uses a qualitative and descriptive approach, with a theory or basis derived from library research, which includes various sources such as books, journals, and articles. This method focuses on understanding social phenomena that occur in society and is used to determine the truth in a reality that occurs. The results of this study indicate that Civics subjects give students the image to have character behaviors such as the spirit of nationalism and patriotism. And the task of Civics teachers is more than simply conveying ideas about how to be good citizens to students it also requires imparting knowledge, motivation, instilling mindsets, and promoting excellent ethical attitudes and behavior.

Keywords: the spirit of nationalism, the role of the teacher, civic education

Copyright (c) 2021 Syofiyah Hasna, Amanda Ramadhan Firdaus, Dinie Anggraeni Dewi, Yayang Furi Furnamasari

$\triangle$ Corresponding author

Email : syofiyahhasna@upi.edu

DOI : https://doi.org/10.31004/edukatif.v3i6.1570

ISSN 2656-8063 (Media Cetak)

ISSN 2656-8071 (Media Online) 
4971 Strategi Guru dalam Menumbuhkan Jiwa Nasionalisme Peserta Didik melalui Pembelajaran Pkn - Syofiyah Hasna, Amanda Ramadhan Firdaus, Dinie Anggraeni Dewi, Yayang Furu Furnamasari

DOI: https://doi.org/10.31004/edukatif.v3i6.1570

\section{PENDAHULUAN}

Artikel ini dibuat bertujuan untuk membahas bagaimana Pendidikan Kewarganegaraan di sekolah dasar digunakan untuk membangun nasionalisme siswa di era globalisasi. Tujuan pendidikan nasional adalah untuk membangun kapasitas dan membentuk watak serta budaya bangsa yang bermartabat sehingga kehidupan bangsa dapat terdidik (Pasal 3 Undang-Undang Nomor 20 Tahun 2003 tentang Sistem Pendidikan Nasional). Tujuannya membantu peserta didik mewujudkan potensi dirinya sebagai warga negara yang baik dan warga negara terdidik yang beriman kepada Tuhan Yang Maha Esa, berilmu, sehat, mandiri, kreatif, demokratis, dan bertanggung jawab.

Globalisasi menyusutkan dunia, memperpendek jarak, dan memungkinkan kejadian di satu lokasi untuk didistribusikan secara luas. Tiga kecenderungan muncul sebagai akibat dari globalisasi: homogenisasi, hibridisasi, dan perbedaan dalam berbagai elemen kehidupan. Homogenitas didefinisikan sebagai meluasnya penggunaan merek dagang barat yang tidak asli oleh orang Indonesia. Hibridisasi terjadi ketika produk global diadaptasi dan dimodifikasi oleh dan untuk pengaturan lokal, dengan kata lain, ketika budaya dan gaya hidup bertabrakan. Globalisasi memiliki kecenderungan untuk menghancurkan prinsip-prinsip luhur bangsa. Banyaknya anak muda yang memilih produk global, budaya lain, dan fesyen hedonistik menunjukkan hal tersebut. Tujuan pendidikan kewarganegaraan di Indonesia adalah untuk menghasilkan warga negara yang cerdas dan baik. Pendidikan kewarganegaraan dalam paradigma baru menekankan pada penciptaan warga negara yang tidak hanya sadar akan hak dan kewajibannya, tetapi juga bagaimana menjalankannya. Tetapi, yang lebih penting, sebagai kebijakan publik, menghasilkan orang-orang cerdas dengan kecerdasan sipil, tugas sipil, dan partisipasi sipil. Salah satu fondasi terpenting yang menentukan perkembangan, kemajuan, dan kualitas hidup masyarakat adalah pendidikan. Suatu pembentukan pengembangan sumber daya manusia ini dapat kita sebut sebagai Pendidikan. Generasi penerus bangsa diciptakan melalui pendidikan. Pembelajaran adalah suatu sistem atau proses untuk mentransfer pengetahuan dari pendidik kepada peserta didik secara terencana atau sistematis dengan tujuan peserta didik mencapai tujuan pembelajarannya secara berhasil dan efisien. Memastikan jika pendidikan harus dilaksanakan secara sistematis supaya tujuannya tercapai, merupakan fungsi dan tujuan awal dari pendidikan nasional. (Retnasari \& Hidayah, 2019).

Pada situasi ini berkesinambungan beserta pembentukkan karakter siswa sebagai akibatnya bisa berlomba, berperilaku, bermoral, rapikan krama dan berkomunikasi kepada warga. Sementara itu pendidik merupakan keliru satu keahlian, yang bermaksut suatu pangkat untuk membutuhkan kemahiran eksklusif menjadi pendidik dan tidak sanggup dilaksanakan kepada seluruh manusia pada luar lingkup pembelajaran. Jauh sebelum berdirinya Indonesia, Indonesia mulai menggunakan istilah nasionalisme. Nasionalisme sangat penting bagi kehidupan berbangsa dan bernegara. Suatu bangsa dapat berdiri tegak dan memiliki rasa identitas yang kuat jika memiliki rasa nasionalisme yang tinggi. Setiap negara, termasuk Indonesia, harus mengkaji nasionalisme sebagai bagian dari proses pembangunannya. Jauh sebelum berdirinya Indonesia, Indonesia mulai menggunakan istilah nasionalisme. Kemerosotan generasi muda telah menyebabkan penurunan nasionalisme. Kecenderungan saat ini adalah generasi muda tidak peduli dengan pertempuran heroik dan kurang memahami kodrat manusia sebagai negara dan negara. Salah satu contohnya adalah bangga menjadi warga negara Indonesia. Memiliki jiwa nasionalisme yang kuat. (Auliyairrahmah et al., 2021).

Guru merupakan salah satu komponen manusia dalam proses belajar mengajar yang membantu mengembangkan potensi sumber daya manusia di daerah pembangunan (Studi et al., 2020). Seorang pengajar tidak hanya berperan untuk mengembangkan akademik siswa tetapi menjadi guru juga harus dapat membentuk karakter nasionalisme siswa sesuai dengan tujuan dari pendidikan Indonesia. Kewarganegaraan merupakan sarana pembinaan dan pemeliharaan cita-cita luhur dan moral yang berlandaskan budaya Indonesia dan diharapkan dapat diimplementasikan dalam kehidupan sehari-hari, baik sebagai individu maupun sebagai anggota masyarakat, warga negara, dan makhluk ciptaan Tuhan (Denik et al., 2020). Peran seorang citizen 
4972 Strategi Guru dalam Menumbuhkan Jiwa Nasionalisme Peserta Didik melalui Pembelajaran Pkn - Syofiyah Hasna, Amanda Ramadhan Firdaus, Dinie Anggraeni Dewi, Yayang Furu Furnamasari

DOI: https://doi.org/10.31004/edukatif.v3i6.1570

teacher tidak hanya untuk menyampaikan gagasan, siswa tidak hanya diajarkan bagaimana menjadi warga negara yang baik, tetapi juga bagaimana mendapatkan pengetahuan, motivasi, mengembangkan pola pikir, dan menumbuhkan sikap dan perilaku moral yang baik. (Ramadhan \& Dewi, 2021).

Kendala atau penghambat pembentukan sikap nasionalis di sekolah adalah kurangnya indoktrinasi dan pengetahuan akan pentingnya sifat kebangsaan oleh siswa, atau kurangnya kedekatan guru dengan lingkungan keluarga atau lingkungan tempat tinggal siswa. Sebutkan ciri ciri nasionalisme Sikap nasionalis Indonesia pada dasarnya tercermin dalam ideologi bangsa, yaitu Pancasila. Ideologi Pancasila memiliki lima prinsip nilai dasar, yang digunakan oleh semua warga negara sebagai pedoman di tingkat individu dan kelompok. Pada usia dini akan lebih baik seorang siswa memiliki belak untuk masa depannya, yaitu dengan adanya penanaman karakter nasionalisme yang di berikan semenjak usia masa sekolah dasar. (Kartika, 2016). Selama periode ini, sikap nasionalisme atau nasionalis siswa sekolah menurun atau memudar. Siswa sering melanggar peraturan sekolah, tidak datang tepat waktu, tidak peduli dengan lingkungan kelas, dan mengganggu upacara bendera dan kuliah instruktur. Jasa pahlawan seolah dilupakan atau dikenang oleh siswa. Secara historis, nasionalisme adalah strategi untuk memerangi penjajah. sepenuh hati, tetapi bentuk nasionalisme saat ini adalah mengisi dan mengembangkan melalui pembelajaran. Hanya dengan belajar keras kita dapat mencapai hasil yang sangat baik di sekolah.

Dengan adanya jurnal ini dibuat bertujuan untuk mengubah kita sebagai pembaca membentuk pribadi manusia yang mempunyai akhlak mulia, sehat lahir maupun batin, dan menjadikan manusia yang memiliki ilmu, cerdas, mandiri, berkreativitas, berdaya guna, dan mampu mengutamakan persoalan bangsa. Dan selalu percaya dan mematuhi amanat Tuhan yang maha kuasa. Artikel ini berfokus pada pertanyaan penelitian dalam konteks ini. 1) Apa peran pendidikan kewarganegaraan dalam membangun rasa patriotisme di kalangan siswa di sekolah dasar? 2) Bagaimana peran guru dalam menanamkan rasa cinta tanah air pada anak.

\section{METODE PENELITIAN}

Peneliti kali ini menggunakan metode penelitian secara kualitatif atau pendekatan deskriptif. Mengenai metode penelitian kualitatif, Semiawan (2010) mendefinisikannya sebagai sarana untuk menyelidiki dan memahami fenomena sentral. Untuk memahami fenomena sentral. peneliti mewawancarai partisipan atau partisipan studi dengan mengajukan pertanyaan umum dan cukup luas. Kemudian kumpulkan informasi yang disampaikan oleh peserta. Informasi biasanya muncul dalam bentuk teks. Lantas mengkaji data pada format kata atau teks. Penelitian ini dilakukan dengan terlebih dahulu menetapkan fokus penelitian, kemudian mencari sumber teori, dan terakhir menganalisis teori dan data yang dikumpulkan untuk menjelaskan dan menarik kesimpulan. Temuan-temuan penelitian kepustakaan dari berbagai referensi seperti buku dan jurnal, serta kajian dan analisis yang lebih mendalam berdasarkan data atau teori analisis deskriptif, digunakan sebagai sumber penelitian. Sebelum menarik kesimpulan, lakukan analisis yang lebih rinci terhadap data yang dikumpulkan dan urutkan untuk memudahkan pengambilan keputusan. Tujuan dari penelitian ini adalah untuk membuat materi pelajaran baru lebih dikenal melalui sarana komunitas yang lebih luas, menyajikan penilaian utama dari subjek diskusi, menggeneralisasi pemikiran dan memperluas teori sementara.

\section{HASIL DAN PEMBAHASAN PENELITIAN}

\section{Pendidikan Kewarganegaraan Di Sekolah Dasar}

Pendidikan Kewarganegaraan di Sekolah Dasar ditunjukkan dalam lampiran Menteri Pendidikan Nasional Nomor 22 Tahun 2006, yang menyatakan bahwa "mata pelajaran pendidikan kewarganegaraan adalah mata pelajaran yang menitikberatkan pada pembentukan warga negara yang memahami dan mampu melaksanakan hak dan kewajibannya menjadi warga negara. warga negara Indonesia yang cerdas, terampil, 
4973 Strategi Guru dalam Menumbuhkan Jiwa Nasionalisme Peserta Didik melalui Pembelajaran Pkn - Syofiyah Hasna, Amanda Ramadhan Firdaus, Dinie Anggraeni Dewi, Yayang Furu Furnamasari

DOI: https://doi.org/10.31004/edukatif.v3i6.1570

dan berkarakter yang diamanatkan oleh Pancasila dan UUD 1945 sementara tujuannya jelas, siswa harus dapat melakukan hal berikut:

1. Memikirkan masalah kewarganegaraan secara kritis, rasional dan kreatif.

2. Ikut serta dalam kegiatan masyarakat secara aktif dan bertanggung jawab. Kemasyarakatan, nasional dan nasional dan kegiatan anti korupsi, serta mengambil tindakan yang bijaksana.

3. Mengembangkan diri secara aktif untuk dapat hidup bersama suku bangsa lain, mereka harus demokratis dan membentuk diri sesuai dengan jati diri bangsa Indonesia.

4. Memakai teknologi informasi dan komunikasi untuk berkomunikasi dengan negara lain secara langsung maupun tidak langsung dalam hukum dan peraturan dunia.

Negara harus menyelenggarakan pendidikan kewarganegaraan karena setiap generasi adalah manusia baru yang harus memperoleh informasi, sikap, nilai, dan keterampilan dalam rangka mengembangkan warga negara yang berkarakter dan cerdas (smart and worthy citizen) yang dapat berperan serta dalam kehidupan masyarakat, bangsa, dan negara. (Kurniawan, 2013).

Pandangan hidup warga negara Indonesia dan landasan ideologinya adalah Pancasila, hasil perenungan mendalam oleh putra putri negara. Pancasila ini adalah sebagian dari esensi bangsa Indonesia yang telah dibungkam oleh peradaban barat selama beberapa dekade (Lestari et al., 2019). Sebagai hasilnya, siswa diharapkan dapat mengembangkan keterampilan yang dibutuhkan untuk menjadi ilmuwan dan profesi yang berselera tinggi identitas nasional yang kuat dan cinta tanah air, serta menjadi demokratis dan beradab. Selanjutnya, kompetensi tersebut diharapkan dapat membantu siswa berkembang menjadi warga negara yang berdaya saing dan disiplin yang secara aktif tertarik untuk membangun kehidupan yang damai berdasarkan sistem nilai Pancasila. Sehingga dari penjelasan ini dapat disimpulkan bahwa kompetensi siswa pada biodang Pendidikan tidak akan pernah dapat terpisahkan dengan filsafat bangsa.

Pendidikan Kewarganegaraan mirip dengan Civics Education, yang diajarkan di setiap negara. Pendidikan Kewarganegaraan merupakan topik kajian yang memiliki sifat interdisipliner (antar bidang) daripada monodisiplin karena pengetahuan yang membentuk ilmu kewarganegaraan berasal dari berbagai disiplin ilmu. Oleh karena itu, diperlukan kontribusi Ilmu politik, hukum, filsafat, sosiologi, administrasi negara, ekonomi, dan sejarah perjuangan bangsa adalah beberapa bidang yang dipelajari, serta kebudayaan, untuk mengkaji dan mengembangkannya. (Buol et al., n.d.).

Pendidikan Kewarganegaraan di SD dan SMA mencakup topik-topik seperti persatuan dan kesatuan bangsa, serta membina kerukunan antarumat beragama. Norma, misalnya, kita diharuskan mengikuti pedoman hukum; jika kita tidak melakukannya, kita mungkin menghadapi denda atau penjara. Kita harus mengikuti hukum dan peraturan, seperti peraturan sekolah. Sebagai contoh, sebagai manusia, kita berkewajiban untuk memperjuangkan hak asasi kita. Ketika ada masalah, kebutuhan warga, misalnya, diperhatikan. Kaitan antara Pancasila dan UUD 1945 misalnya, tercermin dalam UUD Negara. Pemilu, misalnya, adalah contoh kekuasaan dan politik. (Mediatati, 2019).

Istilah PKn mengacu pada mata pelajaran dalam kurikulum sekolah. PKn bertujuan untuk mendorong perkembangan moral peserta didik sesuai dengan nilai-nilai Pancasila, sehingga mereka dapat mencapai perkembangan yang optimal dan menggunakannya dalam kehidupan sehari-hari. PKn berupaya mewujudkan manusia seutuhnya yang merupakan perwujudan kepribadian Pancasila dan mampu melaksanakan pembangunan masyarakat Pancasila. Tanpa PKn, segala kecerdasan atau akal, serta kemajuan ilmu pengetahuan dan teknologi, serta keterampilan dan ketangkasan, tidak cukup untuk menjamin terbentuknya masyarakat Pancasila. (Min et al., 2021).

Pernyataan ini menunjukkan pentingnya PPKn, khususnya dalam membangun kepribadian manusia Indonesia yang berkepribadian penuh dengan nilai-nilai Pancasila. Akibatnya, PKn tidak dapat dipisahkan dari pendidikan nasional dalam arti sebagai komponen esensial dari sistem pendidikan nasional. Tujuan PPKn 
4974 Strategi Guru dalam Menumbuhkan Jiwa Nasionalisme Peserta Didik melalui Pembelajaran Pkn - Syofiyah Hasna, Amanda Ramadhan Firdaus, Dinie Anggraeni Dewi, Yayang Furu Furnamasari

DOI: https://doi.org/10.31004/edukatif.v3i6.1570

adalah untuk menambah ilmu pengetahuan dalam rangka meningkatkan ketaqwaan kepada Tuhan Yang Maha Esa, mencerdaskan kehidupan bangsa, meningkatkan akhlak, memantapkan kepribadian, dan menjiwai jiwa bangsa sehingga dapat tumbuh menjadi manusia pembangunan yang andal dan mandiri yang bersama-sama bertanggung jawab atas pembangunan bangsa.

\section{Nasionalisme}

1. Pengertian Nasionalisme

Nasionalisme adalah paham bahwa loyalitas tertinggi seorang individu harus tunduk pada negara. Perasaan mendalam dengan ibu pertiwi, tradisi lokal dan pejabat lokal selalu ada dalam sejarah dan memiliki keuntungan yang jelas.Pemahaman di atas dapat membawa kita pada kesimpulan bahwa nasionalisme adalah pemahaman akan rasa cinta dan pengabdian yang tinggi terhadap negara karena mereka memiliki kesamaan identitas dan memahami pendirian dan keyakinan suatu negara dimana mereka mengalami rasa memiliki dan persatuan.

Rasa cinta yang wajar terhadap tanah air, pemahaman yang mendorong terciptanya kedaulatan, serta kesepakatan untuk membentuk negara berdasarkan persamaan nasional, serta menjadi langkah dan tujuan awal dalam kegiatan budaya dan ekonomi, ini biasa disebut dengan nasionalisme (Membangun \& Berjiwa, 2019). Kebangkitan kesadaran diri suatu bangsa bukanlah keadaan pikiran yang mengilhami sekelompok orang untuk bersatu dan bertindak sesuai dengan nilai-nilai budaya bersama mereka (nasionalisme). Media pendidikan canggih apapun tidak dapat menggantikan peran pengajar dalam proses penanaman nilai-nilai positif pada anak (Setiawan et al., 2017). Akibatnya, pemulihan identitas siswa memerlukan model yang hanya dapat ditemukan dalam kepribadian guru. Kita sebagai seorang pengajar yang sudah diberikan amanat di negara ini sudah seharusnya mampu untuk membekali siswa kita suri teladan yang baik.

Karena berakar pada etnisitas dan budaya pramodern, nasionalisme lebih merupakan fenomena budaya daripada fenomena politik. Kalaupun nasionalisme diterjemahkan ke dalam gerakan politik, itu hanya di permukaan, karena gerakan politik nasionalis pada akhirnya dimotivasi oleh dorongan budaya, terutama ketika terjadi krisis identitas budaya. Dari perspektif ini, nasionalisme sebagai gerakan politik merupakan sarana untuk merebut kembali kebanggaan etnis sebagai landasan untuk membangun negara berdasarkan kesamaan budaya. Rasa kebersamaan sosial, semangat rela berkorban, dan patriotisme semuanya bisa bersumber dari semangat nasionalisme. Semangat kebangsaan suatu bangsa akan diperkuat melalui rasa persatuan sosial. Ada berbagai macam nasionalisme, antara lain:

1. Nasionalisme sipil (civil nationalism) adalah bentuk nasionalisme di mana negara menarik kepatutan politik dari keterlibatan aktif warganya. Keanggotaan suatu negara sepenuhnya bersifat sukarela. JeanJacques Rousseau menciptakan nasionalisme semacam ini, yang ia gunakan sebagai dasar tulisantulisannya.

2. Nasionalisme etnis, juga dikenal sebagai etnonasionalisme, adalah ketika kebenaran politik suatu masyarakat berasal dari budaya asal atau etnisitasnya. Keanggotaan suatu bangsa diwariskan.

3. Negara mencapai kebenaran politik sebagai wujud alamiah dan manifestasi suatu bangsa atau ras dalam nasionalisme romantis, sejenis nasionalisme etnis. Budaya etnik yang sejalan dengan nilai-nilai romantisme menjadi fokus nasionalisme romantisme.

4. Nasionalisme budaya adalah bentuk nasionalisme di mana negara memperoleh realitas politik dari budaya bersama yang tidak diturunkan dari generasi ke generasi seperti warna kulit.

5. Nasionalisme negara adalah jenis nasionalisme sipil yang sering mencakup nasionalisme etnis. Bangsa dalam nasionalisme negara adalah komunitas yang berkontribusi dalam pemeliharaan dan kekuatan negara.

6. Nasionalisme agama adalah bentuk nasionalisme di mana legitimasi politik negara berasal dari kesetaraan agama. 
4975 Strategi Guru dalam Menumbuhkan Jiwa Nasionalisme Peserta Didik melalui Pembelajaran Pkn - Syofiyah Hasna, Amanda Ramadhan Firdaus, Dinie Anggraeni Dewi, Yayang Furu Furnamasari

DOI: https://doi.org/10.31004/edukatif.v3i6.1570

2. Tujuan Nasionalisme

Tujuan nasionalis, kata nasionalisme digunakan dalam arti yang kita gunakan sekarang. Di antara kegunaan ini, yang paling penting adalah

1) Proses pembentukan atau pengembangan suatu negara

2) Suatu sistem atau kesadaran terkait dengan negara

3) Bahasa dan simbol nasional

Tujuan nasionalisme itu sendiri dapat tumbuh dan berkembang melalui pola asuh. Pengasuhan merupakan upaya orang tua untuk mengajarkan, membimbing, dan menumbuhkembangkan nilai-nilai nasionalis yang positif, dialog dan pertukaran nilai-nilai kasih sayang kepada anaknya dalam keluarga orang tuanya. (Nadifah et al., 2021).

Ringkasnya, tujuan nasionalisme adalah untuk mempersatukan bangsa, namun arus globalisasi kini menjadi sumber penerus bangsa yang berujung pada kemunduran nasionalisme. penanaman nasionalisme anak.

3. Cara Membangun Nasionalisme

Masalah di era globalisasi, nasionalisme dan patriotisme bukan satu-satunya masalah yang dihadapi Indonesia. Amerika Serikat adalah negara adidaya politik dan ekonomi. Ekonomi budaya. Bahkan mereka yang tak tertandingi harus berusaha sekuat tenaga untuk menanamkan patriotisme dan nasionalisme pada warganya. Dengan bangsa lain, sebagai contoh, bahkan Malaysia akhir-akhir ini ramai membahas perkembangan nasionalisme dan patriotisme di negaranya.

Nasionalisme dipahami sebagai kesetiaan tertinggi kepada negara, dan kesetiaan ini muncul dari pengakuan identitas bersama, meskipun berbeda dari orang lain (Dole, 2021). Ringkasnya, sementara pembangunan nasionalisme saat ini menghadapi tantangan berat, perlu diajukan kembali tema pembangunan nasionalisme. Selain itu, di sisi lain, pembahasan nasionalisme Indonesia belum cukup mendalam.

4. Pengertian Sikap Nasionalisme

Sikap nasionalisme dapat dipahami sebagai kesetiaan tertinggi terhadap bangsa, loyalitas ini muncul dari pengakuan identitas bersama, meskipun berbeda dengan orang lain. Sikap nasionalis Indonesia pada dasarnya tercermin dalam ideologi bangsa, yaitu Pancasila. Ideologi Pancasila memiliki lima nilai dasar sebagai pedoman. Semua warga negara, baik individu maupun kolektif. (Permatasari et al., 2021)

Ringkasnya, nasionalisme adalah rasa cinta tanah air yang tertinggi, pemahaman (ajaran) bangsa sendiri, dan sikap cinta tanah air, yaitu mencintai dan ingin membangun rumah tangga yang lebih baik.

5. Bentuk-bentuk sikap nasionalis.

Sebagai warga negara yang peduli terhadap keutuhan atau kesatuan negara, tentunya harus memiliki sikap nasionalis sebagai berikut:

1) Menjaga persatuan dan kesatuan negara

2) Menghargai dan menggunakan barang-barang dalam negeri.

3) Menjaga negara dan reputasinya yang baik

4) Bersedia membela negara dari ancaman negara lain

5) Menggunakan bahasa Indonesia dengan benar

Ringkasnya, warga negara Indonesia memiliki berbagai macam bentuk nasionalisme baru, seperti mencintai dan mengembangkan budaya sendiri serta meletakan kebutuhan nasional dibandingkan keperluan individunya, bentuk-bentuk ini seperti sikap nasionalis.

6. Faktor-faktor yang mempengaruhi sikap nasionalisme.

Negara telah menjadi alat politik yang sempit dan menimbulkan pertanyaan mengapa nasionalisme Indonesia seringkali lebih rapuh, dan kapan negara otoriter orde baru akan menjadi lebih rapuh. Kemunduran, sistem demokrasi mulai terbuka, hal ini diakibatkan oleh faktor-faktor berikut ini yaitu: 
4976 Strategi Guru dalam Menumbuhkan Jiwa Nasionalisme Peserta Didik melalui Pembelajaran Pkn - Syofiyah Hasna, Amanda Ramadhan Firdaus, Dinie Anggraeni Dewi, Yayang Furu Furnamasari

DOI: https://doi.org/10.31004/edukatif.v3i6.1570

1) Faktor internal

a) Kepemimpinan, ketika seorang pemuda jauh dari masa pembaruan impiannya, dan dia malu dengan hasil kerja kepemimpinannya saat ini.

b) Perilaku keluarga dan sanak saudara sekitarya yang tidak menunjukkan rasa cinta tanah air, sehingga semua generasi muda mengikuti karakter tersebut.

c) Demokratisasi yang melampaui batas adat dan etiket serta manifestasi yang meluas, telah menimbulkan kecemasan di kalangan pemuda dan optimisme telah hilang, sehingga yang tersisa hanya kemalasan, keegoisan dan kemarahan.

2) Faktor penyebab eksternal

a) Besarnya globalisasi yang berdampak pada moral masyarakat saat ini. Mereka lebih menyukai budaya bangsa lain daripada budaya Indonesia.

b) Untuk memahami liberalisme yang dianut oleh negara-negara Barat yang menularkan dampak kehidupan negara kita. Semua warga negara memahami liberalisme, sebagai sikap individualisme yang selalu membayangkan dirinya tidak memperhatikan situasi di sekitarnya atau acuh tak acuh terhadap pemerintah. Guru harus mampu menguasai ketiga aspek tersebut karena untuk mencapai tujuan pembelajaran sejarah.

Pernyataan tersebut dapat disimpulkan bahwa faktor internal dan eksternal mempengaruhi sikap seseorang terhadap nasionalisme. Faktor internal meliputi masalah internal seperti masalah politik dalam negeri yang semakin membesar, adanya faktor lingkungan sekitar yang kurang menekankan sikap nasionalisme. Sedangkan dari faktor eksternal meliputi adanya faktor globalisasi yang menyebabkan masyarakat Indonesia cenderung bergaya kebarat-baratan

\section{Peran Guru Dalam Membangkitkan Jiwa Nasionalisme}

Kinerja guru dan kinerja pendidikan ditentukan pada tingkat institusional dan instruksional; Peran strategis ini sesuai dengan Undang-Undang Nomor 14 Tahun 2015 Tentang Pengajar dan Dosen, yang mengakui guru sebagai tenaga profesional dan agen pembelajaran. Hanya mereka yang memiliki kualifikasi akademik, keterampilan, dan sertifikasi pendidik yang diperlukan untuk setiap jenis dan gelar pendidikan yang memenuhi syarat yang dapat menjalankan tugas seorang guru secara profesional.

Peran guru sebagai profesional adalah mewujudkan terselenggaranya pembelajaran yang sesuai dengan norma-norma profesi guna menjamin bahwa semua warga negara memiliki akses yang merata terhadap pendidikan yang bermutu tinggi. Peran guru tidak hanya sebagai agen pengubahan antara lain berkaitan dengan peran guru sebagai penyedia, motivator, booster, pengayaan pengkajian serta kreativitas pembelajaran bagi siswa. Guru harus mampu meningkatkan kinerja dan profesionalismenya dalam menyikapi perubahan dunia pendidikan dalam rangka menunaikan tugas tersebut. (Dasar, 2016). Guru dan dosen bekerja sebagai tenaga profesional untuk menyelenggarakan sistem pendidikan nasional dan memenuhi tujuan pendidikan nasional, seperti mengembangkan potensi peserta didik sebagai manusia yang beriman dan bertakwa kepada Tuhan Yang Maha Esa, berakhlak mulia, sehat, berilmu, pandai, kreatif, warga negara yang mandiri, demokratis, dan bertanggung jawab.

Dalam pelaksanaan pembelajaran, guru selalu memiliki peranan penting didalamnya. Guru merupakan kunci keberhasilan pencapaian tujuan pembelajaran (Sejarah, 2021). Dalam mata pelajaran Pendidikan Kewarganegaraan, seorang guru tidak hanya memberikan siswa pengetahuan kognisi, tetapi juga mengajarkan siswa pengetahuan psikomotor dan emosi. Guru memberikan pembelajaran kepada siswa ketika menerapkan kurikulum 2013, termasuk tiga bidang psikomotor kognitif. Bidang emosional berkaitan dengan pembelajaran yang ditransferkan oleh pengajar, bidang psikomotor berkaitan dengan keterampilan yang dapat dilakukan siswa setelah menerima materi, dan bidang emosional berkaitan dengan sikap, kejujuran dan toleransi berkaitan dengan pendidikan karakter. Disiplin, ketekunan, inovasi, kemandirian, toleransi, merakyat, 
4977 Strategi Guru dalam Menumbuhkan Jiwa Nasionalisme Peserta Didik melalui Pembelajaran Pkn - Syofiyah Hasna, Amanda Ramadhan Firdaus, Dinie Anggraeni Dewi, Yayang Furu Furnamasari

DOI: https://doi.org/10.31004/edukatif.v3i6.1570

mempunyai pikiran yang kritis, semangat kebangsaan, cinta terhadap tanah kelahirannya, penghargaan atas kinerja, ramah, bersosialisasi, rukun dan sangat menyukai baca. Ramah lingkungan. Kepedulian serta kewajiban sosial.

Menjadi Pengajar wajib bisa menguasai ketiga aspek tadi karena untuk dapat mencapai tujuan Pembelajaran Sejarah. Seorang pengajar sejarah selain menjadi seseorang pendidik, dia wajib bisa sebagai fasilitator, mentor dan stimulus kreatif bagi proses perkembangan anak didik yang dilakukan secara berkelanjutan, menyatakan bahwa kiprah dan sifat pengajar itu multifungsi, yaitu:

(1) Pengajar menjadi pembimbing

(2) Pengajar menjadi pengajar,

(3) Pengajar menjadi jembatan antar generasi,

(4) Pengajar menjadi peneliti,

(5) Pengajar menjadi konsultan,

(6) Pengajar menjadi pendorong,

(7) Pengajar menjadi seseorang otoritas.

Kami akan membahas masing-masing peran ini satu per satu, termasuk: Sebagai guru, guru bertugas memberikan pengajaran di sekolah (kelas). Dia memberikan kelas sedemikian rupa sehingga siswa sepenuhnya memahami semua informasi yang disajikan. Instruktur, sebagai pemandu, bertanggung jawab untuk membantu siswa dalam mengidentifikasi dan memecahkan kesulitan mereka sendiri, serta belajar tentang diri mereka sendiri dan beradaptasi dengan lingkungan mereka. Sebagai pemimpin, guru bertanggung jawab untuk mengawasi kegiatan belajar siswa, membuat rencana pengajaran kelas, melakukan pengelolaan pembelajaran yang terbaik, pengelolaan kelas, dan mengatur disiplin kelas secara demokratis. Guru dipandang sebagai individu yang paling berpengetahuan, seolah-olah dia adalah seorang ilmuwan (Sudirgayasa, n.d.). Guru sebagai pribadi, yaitu, setiap instruktur harus memiliki kualitas yang dihargai oleh siswa, orang tua, dan masyarakatnya.

Guru sebagai penghubung, terutama sekolah, dipercayakan untuk menampung tujuan, masalah, kebutuhan, minat, dan harapan masyarakat di satu sisi, dan di sisi lain, tanggung jawab untuk menyampaikan dan menyampaikan informasi, teknologi, dan budaya. yang terus berkembang dengan pesat. Guru sebagai pembaharu, terutama fungsi guru sebagai pembaharu, karena melalui kegiatan guru seperti penyampaian ilmu pengetahuan dan teknologi, model positif, dan lain-lain, murid akan ditanamkan semangat pembaruan. Guru sebagai pengembangan, yaitu instruktur sebagai individu dan sebagai guru profesional, dapat memanfaatkan setiap kesempatan yang ada untuk membantu keberhasilan inisiatif pengembangan masyarakat, seperti kegiatan keluarga berencana, pengabdian masyarakat, koperasi, pembangunan jalan, dan sebagainya.

Mata pelajaran PKn menaruh anak didik citra buat mempunyai perilaku yg berkarakter misalnya semangat nasionalisme dan patriotisme. Penumbuhan rasa nasionalisme dan patriotisme dapat dilakukan oleh guru pada materi pahlawan perjuangan kemerdekaan Indonesia, atau materi lain yang berkaitan dengan mata pelajaran sejarah. Dalam memilih buku pelajaran, guru juga harus mempertimbangkan nilai anak, dengan harapan dapat mengajarkan kepada siswa tentang penanaman pendidikan karakter. (Fauziah, 2014).

Tugas guru PKn lebih dari sekadar menyampaikan gagasan tentang bagaimana menjadi warga negara yang baik kepada siswa; itu juga memerlukan pemberian pengetahuan, motivasi, menanamkan pola pikir, dan mempromosikan sikap dan perilaku etis yang sangat baik. Tingkat pemahaman dan perkembangan siswa harus disesuaikan dengan pengetahuan atau pengenalan suatu nilai, serta contoh sikap, perilaku, atau tindakan. Selain contoh positif, dapat disajikan contoh sikap dan tindakan negatif, seperti mengikuti aturan dan tata tertib di sekolah, rumah, dan masyarakat, hidup rukun meskipun berbeda, disiplin, dan menghormati guru. Memberikan contoh sikap dan perilaku negatif terutama yang terjadi di lingkungan sekitar siswa dan sejalan dengan tingkat psikologis siswa. Ia sering terlambat ke sekolah, sering menyela teman yang sedang belajar, 
4978 Strategi Guru dalam Menumbuhkan Jiwa Nasionalisme Peserta Didik melalui Pembelajaran Pkn - Syofiyah Hasna, Amanda Ramadhan Firdaus, Dinie Anggraeni Dewi, Yayang Furu Furnamasari

DOI: https://doi.org/10.31004/edukatif.v3i6.1570

tidak patuh pada guru, tidak disiplin, dan suka mencuri barang milik temannya, misalnya. Contoh negatif harus disertai dengan implikasi negatif yang mereka miliki pada siswa maupun siswa lainnya.

Di era globalisasi seperti sekarang ini, banyak pelajar yang lupa menjadi orang Indonesia sendiri dan mulai tidak cinta tanah air. Disinilah peran seorang guru sejarah benar-benar diuji, karena seorang pengajar khususnya sebagai guru Pendidikan kewarganegaraan tidak sekedar hanya membekali ilmu pengetahuan, namun juga mendidik siswa satu persatu sesuai dengan tujuan pembelajaran sejarah. Guru juga orang tua, dan mendidik anak sesuai dengan norma sosial yang berlaku, karena ketika anak bersekolah, sudah menjadi tanggung jawab guru untuk mendidik anak-anak tersebut.

\section{KESIMPULAN}

Berdasarkan hasil penelitian dan pembahasan dapat dikemukakan bahwa pendidikan memegang peranan penting dalam menanamkan rasa patriotisme pada generasi muda bangsa di Indonesia. Pendidikan kewarganegaraan di sekolah dasar memainkan peran penting dalam menanamkan rasa nasionalisme pada anak muda yang memiliki prinsip-prinsip Pancasila. Di era globalisasi, misi dan tujuan pendidikan kewarganegaraan harus diperluas semaksimal mungkin. Membangun kemampuan berpikir kritis dan sistematis, serta kemampuan berkolaborasi dengan orang lain, bertanggung jawab, dan menyelesaikan masalah tanpa kekerasan, berdasarkan prinsip-prinsip Pancasila sebagai nilai-nilai bangsa. Sangat penting untuk membangun suasana nasinalisme di kelas melalui pendidik nasinalisme terhadap anak-anak agar pendidikan kewarganegaraan berfungsi secara efisien. Pendidikan kewarganegaraan yang mengikuti proses yang benar akan menghasilkan warga negara muda yang memiliki rasa identitas nasional yang kuat, memungkinkan Indonesia untuk mengaktualisasikan masyarakat sipil di era globalisasi. seseorang pengajar hanya berperan menaruh ilmu pengetahuan berupa kognitif, akan tetapi jua bisa menguasai dan mendidik anak didik pada aspek afektif dan psikomotorik. Tentunya dengan upaya menyelaraskan realitas kekinian, merasionalisasi situasi, mengkontekstualisasikan nilai-nilai Pancasila, dan menginternalisasi nilai-nilai Pancasila berdasarkan UUD 1945.

\section{DAFTAR PUSTAKA}

Auliyairrahmah, A., Djazilan, S., \& Hartatik, S. (2021). Implementasi Pendidikan Karakter Integritas Sub Nilai Kejujuran Melalui Program Kantin Kejujuran Di Sekolah Dasar. EDUKATIF: Jurnal Ilmu Pendidikan, 3(6), 3565-3577.

Buol, K., Lakea, N., Buol, K., Negeri, S. D., Kabupaten, L., \& Bahwasanya, B. (N.D.). Implementasi Dan Implikasi Pendidikan Agama Islam Dalam Meningkatkan Nilai-Nilai Implementasi Pendidikan Agama Islam Dalam Meningkatkan Nilai-Nilai Nasionalisme Pendidikan Agama Islam Dalam Meningkatkan Nilai-Nilai Nasionalisme Siswa Di SD. 885-896.

Dasar, J. P. (2016). 1) , 2). 3(4), 65-72.

Denik, Saputri, E. D., \& Khoirotunnisa, A. U. (2020). Peran Guru Ppkn Dalam Menanamkan Jiwa Nasionalisme Siswa Kelas Vii Mts Miftahul Ulum Sitiaji Sukosewu Bojonegoro Denik 1, Ernia Duwi Saputri 2 , Anis Umi Khoirotunnisa' 3 Fkip, Ikip Pgri Bojonegoro. Jurnal Pendidikan Edutama, 1-7. Http://Repository.Ikippgribojonegoro.Ac.Id/986/1/Jurnal Denik\%281\%29.Pdf

Dole, F. E. (2021). Edukatif: Jurnal Ilmu Pendidikan Pengaruh Pendidikan Karakter Terhadap Kedisiplinan Peserta Didik Di Sekolah Dasar. 3(6), 3675-3688.

Fauziah, I. (2014). Peran Guru Dalam Mengembangkan Karakter Peserta Didik. 1-8.

Kartika, D. I. M. (2016). Peranan Guru PPKN Dalam Mengembangkan Karater Dan Sikap Nasionalisme Pada Siswa Dwijendra Denpasar. Jurnal Kajian Pendidikan Widya Accarya FKIP Universitas Dwijendra, 
4979 Strategi Guru dalam Menumbuhkan Jiwa Nasionalisme Peserta Didik melalui Pembelajaran Pkn - Syofiyah Hasna, Amanda Ramadhan Firdaus, Dinie Anggraeni Dewi, Yayang Furu Furnamasari DOI: https://doi.org/10.31004/edukatif.v3i6.1570

3(1), 67-76. Http://Ejournal.Undwi.Ac.Id/Index.Php/Widyaaccarya/Article/View/232

Kurniawan, M. I. (2013). Integrasi Pendidikan Karakter Ke Dalam Pembelajaran Kewarganegaraan Di Sekolah Dasar. Jurnal Pemikiran Dan Pengembangan Sekolah Dasar (JP2SD), 1(1), 37. Https://Doi.Org/10.22219/Jp2sd.V1i1.1528

Lestari, E. Y., Janah, M., \& Wardanai, P. K. (2019). Menumbuhkan Kesadaran Nasionalisme Generasi Muda Di Era Globalisasi Melalui Penerapan Nilai-Nilai Pancasila. Adil Indonesia Jurnal, 1(1), 20-27.

Mediatati, N. (2019). Civics Education And Social Sciense Journal(CESSJ) Volume 1 Nomor 2 Bulan Desember 2019. 1, 70-93.

Membangun, D., \& Berjiwa, M. (2019). Journal Of Civic Education (ISSN:2622-237X) Volume 2 Nomor 2 2019 Peran Pendidikan Kewarganegaraan Dalam Membangun Masyarakat Berjiwa Nasional. 2, 15-20.

Min, D. I., Tahun, P., Kunci, K., Guru, P., \& Nasionalisme, R. (2021). Peran Guru Pendidikan Kewarganegaraan (Pkn) Dalam Menumbuhkan Rasa Nasionalisme Pada Siswa Kelas 4 Di Min 5 Pacitan Tahun Pelajaran 2020-2021.

Nadifah, I., Fauziah, N., Dewi, D. A., \& Indonesia, U. P. (2021). Membangun Semangat Nasionalisme Mahasiswa. 2(02), 93-103.

Permatasari, N. A., Setiawan, D., \& Kironoratri, L. (2021). Edukatif: Jurnal Ilmu Pendidikan Model Penanaman Karakter Disiplin Siswa Sekolah Dasar Pada Masa Pembelajaran Daring. 3(6), 37583768.

Ramadhan, A., \& Dewi, D. A. (2021). Implementasi Nilai-Nilai Pancasila Dalam Meningkatkan Sumber Daya Manusia Indonesia. Jurnal Kewarganegaraan, 5(1), 184-191.

Retnasari, L., \& Hidayah, Y. (2019). Menumbuhkan Sikap Nasionalisme Warga Negara Muda Di Era Globalisasi Melalui Pendidikan Kewarganegaraan Di Perguruan Tinggi (Studi Pada Mahasiswa PGSD UAD). Jurnal Basicedu, 4(1), 79-88. Https://Doi.Org/10.31004/Basicedu.V4i1.303

Sejarah, M. P. (2021). Peran Guru Dalam Membangkitkan Jiwa Nasionalisme Siswa Pada. April. Https://Doi.Org/10.13140/RG.2.2.21724.92801

Setiawan, D., Pendidkan, J., \& Sosial, F. I. (2017). Jurnal Pendidikan Ilmu-Ilmu Sosial Kontribusi Tingkat Pemahaman Konsepsi Wawasan Nusantara Terhadap Sikap Nasionalisme Dan Karakter Kebangsaan. 9(1), 24-33.

Studi, P., Guru, P., Dasar, S., Alma, U., \& Yogyakarta, A. (2020). Pengaruh Metode Storytelling Terhadap Penanaman Karakter Nasionalisme Pada Siswa SD. XI(1), 11-19.

Sudirgayasa, I. G. (N.D.). Peranan Guru Ppkn Dalam Meningkatkan Nasionalisme Siswa Di Smpn 6 Tabanan. 945. 